\title{
The Influence of Strategic Leadership, Business Continuity Planning and Supply Chain Resilience on Organizational Performance: Instrument Validation
}

\author{
Mosaab A Habani \\ Azman Hashim International Business School, Universiti Teknologi Malaysia; College of \\ Business Administration, University of Business and Technology, Jeddah, Saudi Arabia \\ Suzilawati Kamaruddin \\ Azman Hashim International Business School, Universiti Teknologi Malaysia; College of \\ Business Administration, University of Business and Technology, Jeddah, Saudi Arabia
}

Received: October 17, 2021 Accepted: October 26, $2021 \quad$ Published: November 2, 2021

doi:10.5296/bms.v12i2.19101ＵRL: https://doi.org/10.5296/bms.v12i2.19101

\begin{abstract}
Managing supply chain disruption needs to be considered an important activity for organizations. Supply chain risk management implies identifying, assessing, monitoring, and evaluating the potential risks across all supply chain members. The process of risk management emphasizes the improvement of supply chain performance through designing appropriate strategies. To be more precise, the chief responsibility in supply chain risk management is to ensure quality performance during crises and disruptions. Hence, identifying and validating risk-relevant factors that leads to superior business performance is necessary. This study aims to validate the instrument to measure the impact of factors associated with business performance i.e., strategic leadership, business continuity planning, and resilience to disruption. This paper contributes to the literature by developing a comprehensive model that strengthens a firm's resilience to disruption and leads to superior business performance.
\end{abstract}

Keywords: supply chain disruption, performance, strategic leadership, business continuity planning and resilience

\section{Introduction}

Today's ever-changing business environment is often qualified to be highly competitive, dynamic, and complicated. Customers are requesting more variability, better quality, higher 
reliability, and faster delivery. Additionally, organizations are being faced with more uncertainties (Ganbold, 2017) and business threats, which exert a great pressure on them (Păunescu \& Argatu, 2020). However, resilience to disruption and disturbance varies from one organization to another. That is, the firms with higher ability to return to the original conditions after disruption will exhibit better performance.

Considering the profound impact of supply chain disruptions on business survivals, there is a need for formulating key directions of action and essential activities to be performed in order to make the company's supply chain network more resilient in the presence of risk and uncertainty (Park et al., 2016; Păunescu \& Argatu, 2020). Managers are expected to develop a system eligible of identifying, assessing, mitigating, and monitoring risk for better performance. An abiding commitment to the management of risk in the supply chain helps managers to select suitable strategies capable of mitigating different risks, which will eventually upgrade the overall performance of the supply chain (Adeleke et al., 2020). Consequently, in this paper the extant literature is reviewed to identify supply chain risk management strategies which leads to better business performance. Additionally, suitable scales to measure strategic leadership, business continuity planning, resilience to disruption and business performance is introduced. The reminder of the paper is structure as follows: first, the existing literature on strategies for risk management is reviewed; then, research methodology is discussed in detail; last, implications of the study, conclusion, limitations and recommendations for future study are presented.

\subsection{Underpinning Theories}

Structural contingency theory posits that organizations are "open systems", both affect and are affected by environment. According to this theory, the fit between structure and contingencies leads to better organizational performance. In fact, the effectiveness of organizational performance is a function of the fit between structure and contingencies. Additionally, the upper echelon theory developed by Hambrick and Mason in 1984 is one of the primary theories focusing on top powers in organizations in the realm of strategic management research (Yamak et al., 2014). According to this theory, organizational outcome and performance is a reflection of CEO characteristics and actions of powerful actors in the organization (Hambrick \& Mason, 1984). Integrating structural contingency theory and upper echelon theory, this study proposed supply chain risk management strategies that impact business performance i.e., strategic leadership, business continuity planning and resilience to disruption.

\section{Literature Review}

\subsection{Supply Chain Risk Management}

Current business trends are leading to complex and dynamic supply chain. One consequence is that risk is increasing and shifting around supply chain. Managers need to identify and manage risks using a more diverse range of sources and contexts. In the past, when companies manufactured in-house locally-sourced products and sold them directly to the customers, risk was less widespread and was easier to manage. With the increase of 
product/service complication and outsourcing of supply chain across international borders, risk is increasing and the location of risk has transferred through complex changing supply chain (Singh et al., 2009).

Ceryno, Scavarda, Klingebiel, and Yüzgülec (2013) defined supply chain risk as internal or external contingency that can potentially disturb supply chain. From a general perspective, supply chain risk management means handling an undesirable situation by "evaluating risk sources", "analysing probability", and "presenting a suitable strategy" to prevent risk or at least mitigate its effect (Shahbaz et al., 2017). In a different study, Ceryno, Scavarda, Klingebiel, \& Yüzgülec (2013) defined supply chain risk as internal or external contingency that can potentially disturb supply chain.

Effective management of the supply chain is not a simple mission because of the multitudinal nature of disruption factors and the suppliers' individual issues and relationships. Because of the multitudinal nature of disruption factors, an effective supply chain risk management is rarely realised in complete practice. Therefore, the supply chain risk management is designed to take proactive decisions and strategies in a way to meet the objectives successfully (Shenoi et al., 2016).

The main goal of supply chain risk management is to decrease the opportunities of any uncertain case and provide an appropriate set of solutions to manage the situations efficiently and effectively. Supply chain risk management is full of challenges that can result in "higher cost", "wasted materials", and "production error". It has become even more complicated and vulnerable than in the past. Due to loss of commonly recognized definition of Supply chain risk management and very scared literature, it is very difficult to obviously understand it (Shahbaz et al., 2017).

\subsection{Business Performance}

As supply chains increase in importance, organizations are further assumed to become increasingly vulnerable to disruptions emerging from the supply chain. It is therefore important for firms and their management to understand and manage this risk. Effective processes and tools are needed to help firms assess their risk and develop strategies and techniques for avoiding and/or mitigating risk of disruption in their supply chains (Zsidisin et al., 2003). Disruption risks in supply chain management have a great negative influence on the performance of supply chain members. Therefore, the research on supply chain disruption has been more focused on how to mitigate the risks and improve the supply chain performance (Xu et al., 2020).

The evidence indicates that normally firms do not recover quickly from the negative effects of disruptions. The significant negative consequences of disruptions and the lack of any evidence of quick recovery underscore the need to pay close attention to the risk of disruptions (Hendricks \& Singhal, 2005). Empirically, Vakharia and Yenipazarli (2008) asserted that disruptions in the supply chain can lead to a substantive negative financial impact on firm and industry performance. Recently, $\mathrm{Xu}$ et al. (2020) concluded that 
disruption risks in supply chain management have a great negative influence on the performance of supply chain members.

Therefore, it seems rational to argue that resilience to disruption, which is capability of the firm to be alert to, adapt to, and quickly respond to changes brought by a supply chain disruption (Ambulkar et al., 2015), can contribute to business performance. The higher resilience to disruption, the better performance of supply chain will be expected. However, the research into the influence of disruption and resilience to disruption is still undeveloped in many contexts, including Saudi Arabia. It is particularly important to investigate the influence of resilience on performance in Saudi Arabia manufacturing organizations due to the emphasis the Kingdome's government has put on this concept. Saudi Arabia is aiming to transform from an oil-dependent country to an industrial economy by improving its manufacturing sector. Consequently, it is highly important to acknowledge strategies that mitigate supply chain risk and enhance the firms' resilience to disruption and consequently improve the business performance.

\subsection{Strategic Leadership}

Ambiguity or uncertainty in organization is a weak situation that its meaning, boundaries, and implication is not clear and understandable. Managing such an uncertain situation demands organizational leaders to properly define crisis and deliver solution to solve the problem. The main responsibility in the event of disruption is to create positive attitude and feelings among employees by making activities meaningful and sensible (Tsui et al., 2006). Strategic leadership has emerged to be an essential factor of the organizations' profitability, competitiveness, and financial performance. The power of senior executives and the board of directors to envision and point the actions of the organization may significantly affect the competitiveness of the organization (Adeleke et al., 2020).

Empirical evidence confirms the link between strategic leadership and performance. In this regard, Kitonga et al. (2017) carried out a study in Nairobi County, Kenya. A questionnaire

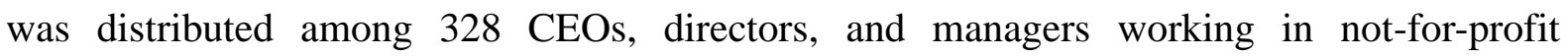
organizations. The results indicated that if not-for-profit leaders use appropriately the strategic leadership, they are likely to improve their organizational performance significantly. Most recently, Tirastittam et al. (2020) investigated factors that impact the firm supply performance. The study used the structural equation modelling to examine the relationships among the variables. Based on the resource-based theory, the findings revealed that a significant positive relationship exists between strategic leadership and performance.

Based on theoretical foundation and extant empirical support, it can be concluded that strategic leadership in an organization leads to the formation of a "strategic intent" and "strategic mission". The output of the strategic leadership is improving business performance. However, despite the fact that strategic leadership has emerged to be an essential factor of the organizations' profitability, competitiveness, and performance, only limited research covers the impact of strategic leadership on firm performance (Tirastittam et al., 2020). 


\subsection{Business Continuity Planning}

Accidental disruptions like pandemics (COVID-19) (Pournader et al., 2020), natural disasters (earthquake, flooding, etc.), losing a key member of the company, and a cyber-attack harming the supply chain can happen anytime to any organization (Păunescu et al., 2018). Companies that lack a proper plan for such risks and disruptions can face supply chain failure and breakage, disruption in financial performance and profitability, and overall negative impact on business performance and operations (Blos et al., 2015). Managing crisis during and after disaster is a challenge to organizations. Therefore, companies are required to design a suitable business continuity plan to enable them to respond to the unknown and complex situations (Păunescu et al., 2018). The business continuity management strategy plays an important role in mitigating risks in the supply chain, thus improving financial performance (Blos et al., 2015).

This statement is supported by structural contingency theory positing that organizational structure is determined by contingencies existing in environment. An effective organizational performance is obtained through a fit between characteristics of the organization and its structure with contingencies. If organizational characteristic fits the contingencies in the environment, more effective performance is expected comparing to a company whose characteristics do not fit the contingencies (Miles, 2012). Applying to this study, it can be concluded that designing a business continuity management strategy in an organization is a response to contingencies in the organization. The business continuity management mitigates risks in the supply chain, thereby improving performance (Blos et al., 2015). In addition, business continuity planning is known as one of the most effective programs to use in the face of crisis, incident, and disaster, specifically for organizations to continue or resume their operations (Charoenthammachoke et al., 2020).

In a study recently conducted by Azadegan et al. (2020), the results of fuzzy set qualitative comparative analysis offers evidence of a strong link between business continuity planning and financial performance. Despite the important role of business continuity planning in mitigating supply chain risk and consequent performance, the empirical evidence investigating business continuity planning and performance is lacking (Păunescu \& Argatu, 2020) due to the emerging nature of the business continuity planning concept.

\subsection{Resilience to Disruption}

Disruptions are becoming increasingly common in today's world disrupting businesses' operations, which consequently making their survival more challenging and businesses are becoming more concerned than before on drafting a business continuity plan (Ghandour, 2014). The results of a study conducted by Păunescu (2017) revealed that the companies investigated were aware of what a business continuity management means and had taken into consideration to some extent its development and adoption. A key goal of each organization should be the development of well-established business continuity plans considering the potential interruption risks and threats to an organization and their associated impacts on 
business operations, as well as promoting proactive management and preparedness to respond to disruption.

Disruption management is one aspect of supply chain risk management, which examines the ability of the supply chain to maintain a high level of performance under the effects of major disruptions (Adam \& Fazleena, 2014). Organization develops a plan or strategy to respond to incidents and business disruptions in order to continue business operations at an acceptable predefined level. It identifies critical activities and develops procedures to ensure that essential functions can continue during and after an incident. Additionally, through the BCMS objectives, aligned with the organization's overall strategic objectives, organization expresses its intent to treat the risks afferent to its business operations (Păunescu, 2017).

It is acknowledged among business continuity practitioners that a business is well prepared for disasters only if a business continuity plan is in place. Creating a business continuity plan, however, has its own challenges and many businesses are still struggling to create a robust plan that is both effective and focused (Ghandour, 2014). According to Filipović, Krišto, and Podrug (2018), the crisis situations are connected with the development of business continuity management. Additionally, designing an appropriate business continuity plan mitigates disruption risk and, in turn, impacts performance. Therefore, we can argue that business continuity plan, as a supply chain risk management, brings resilience to disruption. However, to date, there is an overall scarcity of research into the influence of supply chain risks management strategies (such as business continuity plan) on business performance (Ahmad et al., 2019).

\section{Research Methodology}

Structural equation modelling (SEM) is a statistical approach that evaluates a single analysis model with concurrently predicting multiple variables (Wang \& Wang, 2019). Two SEM approaches of covariance-based SEM (CB-SEM) and Variance-based partial least squares SEM (PLS-SEM) were presented by Hair et al. (2017). PLS-SEM is used when the researcher's focus is on predicting dependent variables. The researcher needs to choose PLS-SEM when the sample size is small and research model is relatively complex.

To validate the research instrument, a questionnaire is distributed among 47 top managers or CEOs who are working in food and beverage industry in Saudi Arabia. Top managers or CEOs are selected because they are actively involved in supply chain risk management practices and are aware of firm's strategies and plans for risk management. Scale to measure research variables is adapted from the past studies. For measuring resilience to disruption, 8-items scale is adapted from Ambulkar et al. (2015). Additionally, Business performance is measured with a scale developed by Li et al. (2015). Strategic leadership is taken from Burns (2008) with 6 items and items for business continuity planning are adapted from Ojha \& Gokhale (2009).

Before data collection, content and face validity is assessed. Accordingly, four experts commented on the questionnaire to ensure items are measuring what they are supposed to 
measure. Additionally, items are checked regarding language transparency, readability and grammatical mistakes. After doing required amendments the questionnaire was distributed among respondents. For reliability assessment, Cronbach's alpha is reported from SPSS. As it is indicated in Table 1 , all the obtained values are above 0.80 which is acceptable. Therefore, the instrument that is chosen for measuring research variables meet the requirements since reliability and validity is established.

Table 1. Reliability

\begin{tabular}{l|c}
\hline Variable & Cronbach alpha \\
\hline Resilience to disruption & 0.918 \\
\hline Business performance & 0.989 \\
\hline Strategic leadership & 0.873 \\
\hline Business continuity planning & 0.911 \\
\hline
\end{tabular}

\section{Conclusion, Implications, Limitations and Recommendations}

Risk is an inseparable part of the life and we all face uncertainty anytime and anywhere, but it does not mean that life cannot move on (Shahbaz et al., 2017). In supply chain literature, risk, which is the source of a crisis, happens when one or more supply chain activities are disturbed, leading to disorder of the flow of products or services (Malini et al., 2009). Organizations have different strategies and approaches to supply chain risk and disruption. This study proposed business continuity planning and strategic leadership as practices and strategies that lead to resilience to disruption, which in turn result in better business performance.

Further studies are suggested to empirically test the proposed model in this paper. It is also worthwhile to include the role of organizational ambidexterity in improving business performance. Ambidexterity is an emerging concept that may contribute to superior business performance by creating balance in organizations.

Regarding theoretical implications, this paper can be considered as one of the pioneering studies in the supply chain risk management field due to its contribution to the body of the knowledge and presenting a new theoretical framework. This paper contributes to the literature by addressing the gaps and focusing on a less discussed topic. Practically, this paper benefits the companies and SMEs by recognizing factors that mitigate risk and increase companies' resilience, which in turn, improve the performance. The results of this study can be also useful for industrial/commercial specialists, scholars and economists to gain a broader understanding of supply chain risk management and its implications on the organizational performance. 


\section{References}

Adam, B., \& Fazleena, B. (2014). Supply Chain Disruption Management: Review of Issues and Research Directions. Munich Personal RePEc Archive.

Adeleke, O. M., Daniel, A. O., \& Ojeleke, O. M. (2020). Supply chain risk management and performance of quoted food and beverage firms in Nigeria. Ilorin Journal of Human Resource Management, 4(1), 263-273. https://doi.org/10.1108/01443570710725563

Ahmad, S., Hadyait, M. A., \& Rashid, M. M. (2019). Effect Of Supply Chain Risk Management On Organization Performance: A Case Study Of National Foods Manooabad Muridke District Sheikhupura. International Journal of Social Sciences and Economic Review, 1(1), 1-7. https://doi.org/10.36923/ijsser.v1i1.22

Ambulkar, S., Blackhurst, J., \& Grawe, S. (2015). Firm's resilience to supply chain disruptions: Scale development and empirical examination. Journal of Operations Management, 33-34, 111-122. https://doi.org/10.1016/j.jom.2014.11.002

Azadegan, A., Mellat Parast, M., Lucianetti, L., Nishant, R., \& Blackhurst, J. (2020). Supply Chain Disruptions and Business Continuity: An Empirical Assessment. Decision Sciences, 51(1), 38-73. https://doi.org/10.1111/deci.12395

Blos, M. F., Hoeflich, S. L., \& Miyagi, P. E. (2015). A general supply chain continuity management framework. Procedia Computer Science, 55(Itqm), 1160-1164. https://doi.org/10.1016/j.procs.2015.07.087

Ceryno, P. S., Scavarda, L. F., Klingebiel, K., \& Yüzgülec, G. (2013). Supply chain risk management: A content analysis approach. International Journal of Industrial Engineering and Management, 4(3), 141-150.

Charoenthammachoke, K., Leelawat, N., Tang, J., \& Kodaka, A. (2020). Business continuity management: A preliminary systematic literature review based on sciencedirect database. Journal of Disaster Research, 15(5), 546-555. https://doi.org/10.20965/jdr.2020.p0546

Filipović, D., Krišto, M., \& Podrug, N. (2018). Impact of crisis situations on development of business continuity management in Croatia. Management (Croatia), 23(1), 99-122. https://doi.org/10.30924/mjcmi/2018.23.1.99

Ganbold, O. (2017). Impact of Environmental Uncertainty on Supply Chain Integration. The Journal of Japanese Operations Management and Strategy, 7(1), 37-56. https://doi.org/10.20586/joms.7.1_37

Ghandour, A. (2014). Identifying Dimensions of Business Continuity Plan from Common Expressions among Business Continuity Professionals. International Journal of Business Administration, 5(3). https://doi.org/10.5430/ijba.v5n3p136

Hambrick, D. C., \& Mason, P. A. (1984). Upper Echelons: The Organization as a Reflection of Its Top Managers. In The Acadamy of Management Review (Vol. 9, Issue 2, pp. 193-206). 
Hendricks, K. B., \& Singhal, V. R. (2005). An empirical analysis of the effect of supply chain disruptions on long-run stock price performance and equity risk of the firm. Production and Operations Management, 14(1). https://doi.org/10.1111/j.1937-5956.2005.tb00008.x

Kitonga, D. M. B., \& Walter Okibo Muema, B. K. (2017). Strategic Leadership Practices And Organizational Performance In Not-For-Profit Organizations In Nairobi County In Kenya. Procedia Economics and Finance, 11(2), 1-214.

Li, G., Fan, H., Lee, P. K. C., \& Cheng, T. C. E. (2015). Joint supply chain risk management : An agency and collaboration perspective. Intern. Journal of Production Economics, 164, 83-94. https://doi.org/10.1016/j.ijpe.2015.02.021

Malini, N., Ismail, C., \& Narayanan, A. (2009). Managing supply chains in times of crisis: a review of literature and insights. The Eletronic Library, 39(7), 535-573.

Miles, J. A. (2012). Management and Organization Theory. In Jossey-Bass.

Ojha, D., \& Gokhale, R. A. (2009). Logistical business continuity planning-scale development and validation. The International Journal of Logistics Management, 20(3), 342-359. https://doi.org/10.1108/09574090911002814

Park, K., Min, H., \& Min, S. (2016). Inter-relationship among risk taking propensity, supply chain security practices, and supply chain disruption occurrence. Journal of Purchasing and Supply Management, 22(2), 120-130. https://doi.org/10.1016/j.pursup.2015.12.001

Păunescu, C. (2017). How prepared are small and medium sized companies for business continuity management? Quality - Access to Success, 18(161), 43-48.

Păunescu, C., \& Argatu, R. (2020). Critical functions in ensuring effective business continuity management. Evidence from romanian companies. Journal of Business Economics and Management, 21(2), 497-520. https://doi.org/10.3846/jbem.2020.12205

Păunescu, C., Popescu, M. C., \& Blid, L. (2018). Business impact analysis for business continuity: Evidence from Romanian enterprises on critical functions. Management \& Marketing. Challenges for the Knowledge Society, 13(3), 1-16. https://doi.org/10.2478/mmcks-2018-0021

Pournader, M., Kach, A., \& Talluri, S. (2020). A Review of the Existing and Emerging Topics in the Supply Chain Risk Management Literature. Decision Sciences, O0(0). https://doi.org/10.1111/deci.12470

Shahbaz, M. S., Rasi, R. Z. R. M., Ahmad, M. F. B., \& Rehman, F. (2017). What is supply chain risk management? A review. Advanced Science Letters, 23(9), 9233-9238. https://doi.org/10.1166/as1.2017.10061

Shenoi, V. V., Dath, T. N. S., \& Rajendran, C. (2016). Supply chain risk management in the Indian manufacturing context: A conceptual framework. International Journal of Logistics Systems and Management, 25(3), 313-335. https://doi.org/10.1504/IJLSM.2016.079829 
Singh, A. R., Jain, R., \& Mishra, P. K. (2009). Risk in Supply Chain Management. March. https://doi.org/10.13140/2.1.4093.7923

Tirastittam, P., Jermsittiparsert, K., Waiyawuththanapoom, P., \& Aunyawong, W. (2020). Strategic leadership, organizational innovativeness and the firm supply performance: The mediating role of information technology capability. International Journal of Supply Chain Management, 9(2), 291-299.

Tsui, A. S., Zhang, Z. X., Wang, H., Xin, K. R., \& Wu, J. B. (2006). Unpacking the relationship between CEO leadership behavior and organizational culture. Leadership Quarterly, 17(2), 113-137. https://doi.org/10.1016/j.leaqua.2005.12.001

Vakharia, A. J., \& Yenipazarli, A. (2008). Managing supply chain disruptions. In Foundations and Trends in Technology, Information and Operations Management (Vol. 2, Issue 4). https://doi.org/10.1561/0200000012

Xu, S., Zhang, X., Feng, L., \& Yang, W. (2020). Disruption risks in supply chain management: a literature review based on bibliometric analysis. International Journal of Production Research, 58(11), 3508-3526. https://doi.org/10.1080/00207543.2020.1717011

Yamak, S., Nielsen, S., \& Escribá-Esteve, A. (2014). The Role of External Environment in Upper Echelons Theory: A Review of Existing Literature and Future Research Directions. Group and Organization Management, 39(1), 69-109. https://doi.org/10.1177/1059601113511663

Zsidisin, G. A. G. A., Ragatz, G. L. G. L., \& Melnyk, S. A. S. A. (2003). Effective Practices in Business Continuity Planning for Purchasing and Supply Management. The Eli Broad Graduate School of Management, Michigan State University, Aug, 1-4. http://citeseerx.ist.psu.edu/viewdoc/download?doi=10.1.1.133.2413\&amp;rep=rep1\&amp;typ e $=$ pdf

\section{Copyright}

Copyright for this article is retained by the author(s), with first publication rights granted to the journal.

This is an open-access article distributed under the terms and conditions of the Creative Commons Attribution license (http://creativecommons.org/licenses/by/4.0/). 